\title{
Gyerekek az apjukról - AdorNo BÉKAPERSPEKTÍVÁbÓL
}

\author{
PÁLFI LÁSZLÓ \\ ELTE BTK Történelemtudományok Doktori Iskola
}

Heinz Bude: Adorno für Ruinenkinder: Eine Geschichte von 1968. München, 2018. Carl Hanser Verlag. 126 p. ISBN 978-3-446-25915-7

„Nekünk, a romok gyermekeinek, a bombák repeszei gyermekeinek, akiknek halállal végződő utazásai a maguk módján játszódnak le, és a korábbi díszletek, mint a felrobbant utcák, tető nélküli házak, égő romok, már rég eltűntek, és akiket az élet első pillanataiban, pillantásaiban, kíváncsiságában, az első félig-meddig felfogott érzékekben megpecsételtek, körülzártak, de mivel is?: roncsokkal, szétszaggatott házakkal, betondarabokkal, égő foszforbombákkal és az egyik játszótárs kék sebhelyeivel [...] mindaz, ami az élet első kulisszái mögül és a megsemmisülés fenyegetésének közelebbről szinte már nem is érezhető nyomásából következett - ez a mi nemzedékünk, egy lom-nemzedék, amely vagy eleve félt a háborútól, vagy a háború első napjaiban vált agyonhajszolttá, egy bonyolult okból kifolyólag: mielőtt a férfi háborúba vonul, csinál a nőnek egy gyereket, egy »vagyok-mert-háború-volt«-gyereket. És mi lesz a gyermek gyermekkorával és az ifjúságával? Nem több egy egyszeri bocsánatkérésnél: »Bocsássátok meg, hogy megszülettem!«", idézi Heinz Bude Rolf Dietmar Brinkmann sorait Klaus Bregenz élettörténete kapcsán az Adorno a romok gyermekeinek: Egy történet 1968-ból címet viselő könyvének 54-55. oldalán.
Norbert Elias szociológus A németekröl írt tanulmánykötetének egyik központi témája az apára vágyó német nemzet. A nacionalista német társadalom a nemzetet a német nép nagycsaládjaként értelmezte, ennek megfelelően pedig a német nemzetnek szüksége volt egy apafigurára, aki kijelöli a német nemzet együttélésének kereteit. A II. világháború után a nyugatnémet állam, az NSZK egy amerikai típusú demokrácia felépítéséhez látott hozzá, ahol már a felelős polgár dönt a maga jövőjéről. A német baby boom generációhoz tartozók azzal a fájdalmas ténnyel szembesültek, hogy nincs apjuk. Sőt, magának a nemzetnek sincs apja: a szövetségi köztársaság elnöke csak egy szimbolikus, reprezentatív figura, s mint a szövetségi kancellár, a kormány feje pedig időről időre cserélődik. Sokan nem jöttek vissza a frontról, a hadifogolytáborokból, a Gulágról. És akik túléltek? Nekik azzal kellett szembenézniük, hogy a következő generáció háborús bűnöst lát bennük.

Romok és romok helyén újjáépített épületek vagy éppen teljesen új, a történelmi múltat eltüntetni kívánó építészeti megoldások - ezek határozták meg az 1960as évek német fiataljainak tértörténetét. Elidegenedés és idegenkedés. Elidegene- 
dettség érzése, amelyet az új, kapitalista társadalom szült, és idegenkedés, amelyet a két világháborúban érintett generációval szemben éreztek. Miközben érzelmileg folyamatosan vergődtek, nem volt olyan közeg, amelyhez tanácsért tudtak volna fordulni: a német nők hagyományos intézményi hármasa, a KKK (Kinder, Küche, Kirche - azaz gyermek, konyha, templom) már nem nyújtott számukra olyan hátteret, amely betölthette volna a háború után keletkezett morális vákuumot.

A fiatalok próbáltak olyan példaképeket találni, akik nem kompromittálódtak a korábbi rendszerekkel. A politikai baloldal részéről ilyen volt Theodor Wiesengrund Adorno, a Frankfurti Egyetem szociológiaprofesszora. A nagy hatású személyiség, aki egy egész generáció gondolkodását befolyásolta, aki Lukács Györggyel együtt a nyugati „új baloldal” szellemi atyja. A baloldali német fiatalok benne találták meg a példaképüket, különösen az útkereső fiatal egyetemisták és értelmiségiek. Adornónál és társainál volt a „bölcsek köve”, megvolt az a morális fölényük, ami a jobboldali értelmiségiekből hiányzott. A frankfurti iskola professzorai a nyugati szövetségesek államaiból tértek haza, de marxista elveket vallottak, a fiatalok szemében így duplán győztes elegyet alkottak. Olyan erkölcsi plusszal rendelkeztek, amilyennel a német társadalom nagyobbik része nem: elmondhatták magukról, hogy „tudták előre, hogy a háború után mi lesz", a zsidó közösséghez füzödő kötelékeik révén pedig képesek voltak azoknak az áldozatoknak a nevében szólni, akik már soha többé nem beszélhettek.

Heinz Bude már a bevezető fejezetben visszaviszi az olvasót az 1967-68-as események közegébe. A Die Perspektive címet viselő fejezet egy generáció hangját szólaltatja meg, annak a generációnak a hangját, amelyik nem türi az autoriter struktúrák létét. Az ezt követő hét fejezet közül hat
Bude kortársainak személyes történeteiről szólnak. Az olvasó rajtuk keresztül ismerheti meg a 1968-as események „másodvonalbeli" aktorait. A megszólaltatott szereplők egytől egyig Adorno tanítványai voltak, mindannyian ,,romok gyermekei”. Az utolsó fejezet, Die Übergabe (Az átadás) egy számvetés: Gerhard Schröder koalíciós kormánya (Németországi Szociáldemokrata Párt - Szövetség '90/ Zöldek) ugyanis a „romok gyermekeiből” tevődött össze, a nem politikus kortársaik pedig akkoriban a német akadémiai és kulturális szféra részét képezték.

A könyv hangvétele romantikus visszaemlékezések helyett inkább erősen szubjektív élményekből építkezik, és ebből a pozícióból indul meg az objektivitás felé. Bude már rögtön az elején deheroizálja Benno Ohnesorg halálát, Ohnesorgét, aki kommunista aktivistaként az iráni sah 1967-es látogatása elleni tiltakozás egyik hangadója volt, és aki a rendőri brutalitás áldozata lett - legalábbis ez él a köztudatban. Karl-Heinz Kurras, az Ohnesorgra fegyvert fogó és azt elsütő rendőr viszont a Stasi egyik nyugat-németországi besúgója és a keletnémet Németországi Szocialista Egységpárt (SED) tagja volt, így könnyen lehet arra a következtetésre jutni, hogy felsőbb utasításnak engedelmeskedve, mintegy maga gyártott mártírt a nyugatnémet baloldali fiatalok számára.

$\mathrm{A} z$ ehhez hasonló események hatására fordult át a tiltakozók hangulata egy rombolás iránti vágyba. Erre a müvészet is reagált, segítségül hívta a punkot, azt a neoavantgárd zenei mozgalmat, amelynek célja a struktúrák lerombolása volt. A színi világban Hanna Schygulla és Werner Fassbinder szintén reagált ezekre a törekvésekre. Hozzájuk csatlakozott később Peter Märthesheimer is, a Nyugatnémet Rádió egyik szerkesztője, a kötet egyik szereplője. Märthesheimer, akinek az apja 1940-ben, Norvégia lerohanásakor vesz- 
tette életét, Bude szerint inkább csekély képességekkel volt megáldva. Adorno elöadásait hallgatta ugyan, de egyáltalán nem értette, csupán a szellemi pótapát szerette benne. Märthesheimer a szociáldemokrata Friedrich Ebert Alapítvány ösztöndíjasaként tanult újságírást a Frankfurti Egyetemen, majd ezt követően a német társadalom alsóbb rétegeinek kérdését feszegető Acht Stunden sind kein Tag (Nyolc óra nem egy nap) címü sorozat forgatókönyvírójaként vált viszonylag ismertté.

A könyv figurái közül Peter Gente az igazi lázadó karakter. Abszolút kilóg a sorból, hiszen nem veszítette el az édesapját. Viszont: „fia szemében apja egy "puhapöcs« [Pflaume] volt." (83. o.) És nem a férfiatlanság okán, hanem azért, mert Peter benne látta az elnyomó állam reprezentánsát, az engedelmes német megtestesülését: 1939-ben a Wehrmacht főhadnagyaként vonult háborúba, majd 1951-ben hazatérve bíróként dolgozott Kelet-Berlinben. Gente egy tipikusan nonkonformista karakter: nemcsak a nyugati kapitalizmus ellen lázadozott, hanem a keleti szocialista rezsimeket is erős kritikával illette, különösen a prágai tavasz leverése után. Ahogy a könyv összes szereplője, úgy Gente is a Szocialista Német Diákszövetség (Sozialistischer Deutscher Studentenbund) tagja volt, méghozzá maga Adorno révén jutott annak felsőbb vezetésébe. Gente azon baloldali fiatalok közé tartozott, akik létező apjukkal szembemenve fogadták Adornót szellemi apjukká, miután a családban az elnyomó struktúrát képviselő, terhelt hátterű apával nem tudtak azonosulni.

Bude több helyen is említi az 1954-es labdarúgó-világbajnokságot, annak a német társadalomban betöltött szerepét. A németek vitatható körülmények között született győzelme a német újjáéledés egyik szimbolikus eseménye - de vajon minden német számára? Joschka Fischer, a Szövetség '90/Zöldek politikusa számára öröm volt nézni a német csapatot, így alaposan meglepődött, amikor apjára pillantva könnyeket látott annak szemeiben: a Magyarországról kitelepített sváb apa szíve ugyanis mindvégig magyar maradt. Az egykori német külügyminiszter ismerte tehát az apját, nem úgy, mint fönöke, Gerhard Schröder, aki már kancellár volt, amikor egy fényképen először megpillantotta a sajátját. A fényképen, amelyet Schröder mindvégig kancellári íróasztalán tartott, apja látható, amint a Wehrmacht egyenruhájában harcol Romániában a II. világháború idején.

Schröderé volt az első kormány, amelyet a "romok gyermekei” vezettek. Adódik a kérdés, hogy Helmuth Kohl konzervatív-liberális koalíciós kormányzása után mit tudtak megvalósítani az eredeti elképzeléseikből. Bude szerint a „romok gyermekeinek" vörös-zöld kormánya ugyan különlegesen jó körülmények között alakult meg - az időszak egybeesett Bill Clinton amerikai elnöki ciklusával -, ám az egyenlőség eszméje helyett a neoliberalizmust ültette át a gyakorlatba. Tegyük hozzá, érvelésébe a legkeményebb kritikát még csak bele sem szőtte, nem említi Peter Struckot, a Schröder-kormány védelmi miniszterét, akinek mondata („Németország biztonságát akár a Hindukusban is meg kell védeni") szállóigévé vált. Ami természetesen szöges ellentéte azoknak a szélsőségesen antimilitarista és pacifista jelszavaknak, amelyeket az 1968-as lázadások idején skandáltak a "romok gyermekei".

A könyv gyengesége nem ez a hiányzó Struck-idézet, nem is az azon nyugvó alkotmányértelmezés figyelmen kívül hagyása, hanem inkább a "hópehely-nemzedék" pozitív színben történő ábrázolása. Míg Tibor Fischer, a baloldali Guardian publicistája erős kritikai érzékkel „moaning illiterate snowflakes” („rinyáló írástudatlan 
hópelyhek") jelzővel illeti ezeket a fiatalokat, addig Bude olyanoknak látja őket, akik Corbynt, Mélenchont és Sanderst támogatva, új tudásanyaggal és tudományokkal felvértezve, végül is beteljesítik az 1968-as álmokat.

Bude emellett számos olyan újabb keletü fogalmat, intézményt vél hasznosnak, ír róluk pozitív hangnemben, amelyek pedig, mióta a felsőoktatási intézményekben egyre inkább uralkodóvá váltak, lassan mindenfajta értelmes tudományos párbeszédet veszélyeztetnek. Ilyen a "safe spaces" („védőzóna”) kialakítása egyes amerikai és brit egyetemeken, a "trigger warning" (figyelmeztetés, ha olyan téma tárgyalása következik, amely jelenlévőket sérthet, illetve felhívás a „védőzónába" való vonulás- ra), a „victimbood culture” (az áldozatiság kultúrája, ami azt jelenti, hogy vannak ún. „született áldozatok”, akik a jelen társadalmi struktúrák változatlansága mellett élethossziglan az elnyomottak kategóriájába tartoznak, mint pl. a fekete nők) vagy a "critical whiteness" (általában a fehér ember, illetve az Immanuel Wallerstein-féle globális Észak kulturális és gazdasági fölényének kritikája).

Bude könyve az 1968-as események egyik fontos mikro- és társadalomtörténeti műve. A könyvben olvasottakat öszszegezve azon hallgatók képe tárul az olvasók elé, akik, ha mást nem is tettek, de legalább eljártak a Frankfurti Egyetem előadásaira, látták és magukévá próbálták tenni Adorno üzenetét. 